\title{
Alternation of heterotrophic bacterial and archaeal production along nitrogen and salinity gradients in coastal wetlands
}

5

Gema L. Batanero ${ }^{1}$, Andy J. Green ${ }^{2}$, Juan A. Amat ${ }^{2}$, Marion Vittecoq ${ }^{3,4}$, Curtis A. Suttle, Isabel Reche $^{1,6^{*}}$

${ }^{1}$ Departamento de Ecología e Instituto del Agua, Universidad de Granada, 18071 Granada, Spain

${ }^{2}$ Departamento de Ecología de Humedales, Estación Biológica de Doñana, EBD-CSIC, 41092 Sevilla, Spain.

${ }^{3}$ Tour du Valat, Institut de Recherche pour la Conservation des Zones Humides Méditerranéennes, 10 Arles, 13200 France.

${ }^{4}$ UMR MIVEGEC, IRD, CNRS, Université de Montpellier, Montpellier, France

${ }^{5}$ Departments of Earth, Ocean \& Atmospheric Sciences, Microbiology \& Immunology, and Botany, and the Institute for the Oceans and Fisheries, University of British Columbia, Vancouver, BC, V6T 1Z4, Canada.

$15{ }^{6}$ Research Unit Modeling Nature (MNat), Universidad de Granada, 18071 Granada, Spain

Correspondence to: Isabel Reche (ireche@ugr.es)

Abstract. Coastal wetlands are valuable ecosystems with high biological productivity and diversity, which provide ecosystem services such as a reduction in the inputs of nitrogen into coastal waters, and storage of organic carbon, thus, acting as net carbon sinks. The rise of sea level as a consequence of climatic warming will salinize many coastal wetlands, but there is considerable uncertainty about how salinization will affect microbial communities and biogeochemical processes. We analyzed prokaryotic abundance and heterotrophic bacterial and archaeal production in 112 ponds within nine coastal wetlands from the western Mediterranean coast. We determined the main drivers of prokaryotic abundance and production in these wetlands using generalized linear models (GLMs). The best GLM, including all the coastal wetlands, indicated that the concentration of total dissolved nitrogen (TDN) positively affected the abundance of heterotrophic prokaryotes and heterotrophic archaeal production. In contrast, heterotrophic bacterial production was negatively related to TDN. This negative relationship appeared to be mediated by salinity and virus abundance. Heterotrophic bacterial production declined as salinity, and virus abundance, increased. We observed a switch from heterotrophic bacterial production towards heterotrophic archaeal production as salinity and virus abundance increased. Our results imply 
that microbial activity will change from bacterial-dominated processes to archaeal-dominated processes along with increases of nitrogen inputs and salinity. However, more studies are required to link the mineralization rates of dissolved nitrogen and organic carbon with specific archaeal taxa, to enable more accurate predictions on future scenarios of wetlands salinization and anthropogenic nitrogen inputs.

\section{Introduction}

Wetlands have high productivity, as well as high functional and species diversity (Mitsch \& Gosselink, 2000; Mitsch et al. 2015). Among the ecosystem services they provide, wetlands reduce nutrient loading from freshwater inflow (Verhoeven et al. 2006), and have been described as "the kidneys of the landscape" (Mitsch et al. 2015). Coastal wetlands, in particular, are considered global reservoirs of organic carbon because of their elevated primary productivity and high sedimentation rates that, in the long-term, minimize carbon dioxide emissions to the atmosphere, acting as carbon sinks (Roehm 2005; Chmura et al. 2003; Geertz-Hansen et al. 2011). Therefore, microbial activities such as denitrification and organic carbon production and mineralization mediate these wetland functions and services.

The production of nitrogen fertilizer has enabled increased food production but has drastically disrupted the nitrogen cycle by doubled input of nitrogen to the Earth's surface, and led to environmental problems such as eutrophication (Gruber \& Galloway, 2008; Canfield et al. 2010). This change likely exceeds all other human effects on nutrient cycles (Gruber \& Galloway 2008; Schlesinger 2009) but has received relatively less attention compared to the carbon cycle (Battye et al. 2017). A substantial fraction of this nitrogen, mostly derived from agricultural lands, is transported to rivers and groundwater through runoff and is lost through emissions of ammonia and other nitrogen compounds by denitrification (Schlesinger 2009; Battye et al. 2017). In many estuaries, natural or constructed wetlands modify the nitrogen loading into coastal areas and reduce coastal eutrophication (Walton et al. 2015). These transitional waters include saline wetlands such as natural marshes and multi-pond solar salterns 55 (Razinkovas-Baziukas and Povilanskas, 2012).

Multi-pond solar salterns are present along the coasts of the Mediterranean and Portugal since the Phoenicians, who used evaporation procedures dating from the Emperor Huang era about 2,500 
years B.C. to obtain salt (Baas-Becking 1931; García-Vargas \& Martínez-Maganto 2006). Coastal saline wetlands also have great importance for waterbird conservation and sustainable aquaculture (Britton \& Johnson 1987; Sánchez et al. 2006; Athearn et al. 2009; Walton et al. 2015). Most studies of microbial ecology in coastal wetlands have focused on extremophile microorganisms and their bioenergetic and diversity constraints (Antón et al. 1999; Pedrós-Alió et al. 2000; Oren 2001; Casamayor et al. 2002; Gasol et al. 2004; Ghai et al. 2011); much less is known about moderately halophilic bacteria and archaea in oligo- to eu-saline waters (Hahn, 2006; Herbert et al. 2015). The discovery that archaea are not exclusively extremophiles (DeLong 1992; Fuhrman et al. 1992; Karner et al. 2001) led to studies showing that archaea are abundant, ubiquitous and diverse, with essential roles in carbon and nitrogen cycling (Herndl et al. 2005; Justice et al. 2012; Offre et al. 2013), including mineralizing organic matter under oxic conditions in the ocean (Herndl et al. 2005; Ingalls et al. 2006). The organo-heterotrophic nature of some archaeal groups has been shown for 70 specific carbohydrates (Lazar et al. 2016) and dissolved proteins (Orsi et al. 2016). Archaea also oxidize ammonia, and perform denitrification under anoxic or suboxic conditions (Francis et al. 2007; Offre et al. 2013) with potential implications for nitrogen removal in wetlands (You et al. 2009). However, the prevalence of heterotrophic metabolism in archaea and its biogeochemical relevance are poorly studied. As well, archaeal heterotrophic production patterns along gradients of dissolved organic carbon and nitrogen, and salinity, remain completely unexplored in the literature.

Currently, most wetlands are salinizing as a consequence of climatic warming and freshwater extraction (Herbert et al. 2015; Jeppesen et al. 2015). Coastal wetlands are particularly affected since the rise of the sea level is introducing seawater high up into estuaries (Herbert et al. 2015; Schuerch et al. 2018). Salinization alters water and sediment chemistry and changes biogeochemical reactions

80 (Herbert et al. 2015). Although there is still considerable uncertainty about how salinization affects wetland biogeochemistry, it promotes the release of inorganic nitrogen $\left(\mathrm{NH}_{4}{ }^{+}\right)$and phosphorus $\left(\mathrm{PO}_{4}{ }^{3-}\right)$, with implications for internal wetland eutrophication (Ardón et al. 2013; Weston et al. 2006). Besides, salinization increases the generation of toxic sulfides (Lamers et al. 1998), which play an essential role in wetland $\mathrm{N}$ cycling, inhibiting the final steps of denitrification, and resulting in the emission of nitrogen oxides (Brunet and García-Gil 1996, Laverman et al. 2007). Overall, salinization disrupts 
many ecosystem services provided by wetlands, such as their capacity to store organic carbon (Weston et al. 2011; Luo et al. 2017) and remove nitrogen from water (Herbert et al. 2015; Franklin et al. 2017).

The projected scenario of climatic warming includes both wetland salinization and more 90 nitrogen inputs. These environmental risks interact, with increased nitrogen boosting organic carbon mineralization and reducing carbon storage in coastal marshes (Deegan et al. 2012), while salinization can affect microbial nitrogen removal (Franklin et al. 2017). Our work describes patterns in microbial abundance and heterotrophic bacterial and archaeal production in a broad set of semi-natural and constructed wetlands covering gradients of salinity, dissolved organic carbon, and nitrogen along the

95 Western Mediterranean. Furthermore, we identified the main drivers of these patterns and discussed potential changes in prokaryotic heterotrophic production under future scenarios.

\section{Materials and methods}

\subsection{Study sites}

We sampled 112 saline ponds from nine coastal wetlands during late spring-midsummer of 2011, 2012, and 2013 (Supplementary Table S1). The coastal wetlands were the Odiel marshes (OdielM) at the mouth of the Odiel river, the Veta la Palma (VPalma) fishponds at the mouth of the Guadalquivir river, the Cabo de Gata (CGata) salt pans, Santa Pola (SPola) and El Hondo (Hondo) at the mouth of the Vinalopó river, and the Ebro Delta (EbroD) ponds at the mouth of the Ebro river in Spain, Salin-deGiraud and Saintes-Maries-de-la-Mer at the mouth of the Rhône (Camargue, France), the Molentargius,

105 Santa Guilla, and Santa Caterina ponds (Sardinia, Italy), and Thyna solar salterns (Sfax, Tunisia) (Fig.1a). All the study ponds are located in semiarid or arid areas, under typical Mediterranean climatic conditions, covering large gradients of salinity from hypersaline (solar salt pans) to oligo-mesohaline (brackish) waters (Fig.1b), and microbial productivity (Fig.1c). Solar salterns are often multi-pond systems connected for commercial salt production, which creates a strong salinity gradient from evaporation ponds to crystallizer ponds (Fig.1b). They are natural laboratories across which microbial communities can be compared (Fig.1c). The brackish wetlands that we studied are also crucial for 
sustainable aquaculture and waterfowl conservation (Britton \& Johnson 1987; Walton et al. 2015). Complete location, sampling dates, and physical-chemical and microbiological details for each pond are in Supplementary Table S1.

\subsection{Chemical analyses}

We recorded salinity with a multi-parameter probe (HANNA HI 9828). Water samples with salinity higher than $70 \mathrm{ppt}$ were diluted with Milli-Q water until they were in the operating range of the probe. We measured total nutrient concentrations in unfiltered samples, while we filtered the samples through pre-combusted $0.7-\mu \mathrm{m}$ pore-size Whatman GF/F glass-fiber filters for dissolved nutrient analysis. We measured total phosphorus (TP), and total dissolved phosphorus (TDP) using the molybdenum blue method (Murphy \& Riley, 1962) after persulfate digestion $\left(30 \mathrm{~min}, 120^{\circ} \mathrm{C}\right)$. We analyzed total nitrogen (TN) and total dissolved nitrogen (TDN) by high-temperature catalytic oxidation (Álvarez-Salgado and Miller 1998) using a total nitrogen analyzer (Shimadzu TNM-1), and potassium-nitrate standards. We analyzed dissolved organic carbon (DOC) concentration as non-purgeable organic carbon by hightemperature catalytic oxidation using a total organic carbon analyzer (Shimadzu TOC-V CSH). DOC samples were pre-filtered through pre-combusted Whatman $\mathrm{GF} / \mathrm{F}$ filters $\left(2 \mathrm{~h}\right.$ at $\left.500^{\circ} \mathrm{C}\right)$ and acidified with $\mathrm{H}_{3} \mathrm{PO}_{4}$ (final $\mathrm{pH}<2$ ). We calibrated the instrument using a four-point standard curve of potassium hydrogen phthalate. We purged the samples with phosphoric acid for $20 \mathrm{~min}$, and we set up three to five injections for each sample.

\section{$130 \quad 2.3$ Biological analyses}

We determined chlorophyll- $a(\mathrm{Chl}-a)$ concentration by extracting Whatman GF/F filters in $95 \%$ methanol in the dark for $24 \mathrm{~h}$ at $4{ }^{\circ} \mathrm{C}$ (APHA 1992) through which 50 to $2000 \mathrm{ml}$ of water was filtered. Absorbance was measured at $665 \mathrm{~nm}$ and $750 \mathrm{~nm}$ using a Perkin Elmer Lambda 40 spectrophotometer.

Samples for determining the abundances of prokaryotes (PA) and cyanobacteria (CyA) by flow cytometry (Gasol and del Giorgio, 2000) were collected in cryovials, fixed with 1\% paraformaldehyde and $0.05 \%$ glutaraldehyde in the dark $\left(30 \mathrm{~min}\right.$ at $\left.4{ }^{\circ} \mathrm{C}\right)$, then frozen in liquid nitrogen and stored at -80 ${ }^{\circ} \mathrm{C}$ until analysis. Once defrosted, the samples were diluted ( $\geq 10$-fold) with Milli-Q water to avoid the 
electronic coincidence of the prokaryotic cells. We counted the PA and CyA in a FACScalibur flow cytometer with a laser emitting at $448 \mathrm{~nm}$ and a suspension of yellow-green $1-\mu \mathrm{m}$ latex beads (Polysciences) per sample as an internal standard. The PA samples were stained in the dark (10 min) with a $10 \mu \mathrm{M}$ DMSO solution of Sybr Green I stain (Molecular Probes), run at low speed for $2 \mathrm{~min}$, and detected in bivariate plots of side scatter (SSC) vs. FL1 (Green fluorescence). The CyA samples were run at high speed for $4 \mathrm{~min}$ and detected in bivariate plots of side scatter (SSC) vs. FL3 (Red fluorescence). We obtained the heterotrophic prokaryotic abundance (HPA) by subtracting the cyanobacteria abundance (CyA) from prokaryotic abundance (PA).

Samples for virus abundance (VA) were collected in cryovials, fixed with glutaraldehyde at a final concentration of $0.5 \%\left(15 \mathrm{~min}\right.$ at $\left.4^{\circ} \mathrm{C}\right)$ in the dark, frozen in liquid nitrogen, and stored at $-80^{\circ} \mathrm{C}$ until analysis by flow cytometry (Brussard et al., 2010). Before analysis, we diluted the samples $\geq 100$ fold with TE-buffer $\quad \mathrm{pH} \quad 8.0 \quad\left(\begin{array}{llllll}10 & \mathrm{mM} & \text { Trishydroxymethyl-aminomethane, } & 1 & \mathrm{mM}\end{array}\right.$ ethylenediaminetetraacetic acid) to avoid the electronic coincidence in virus particle counts. We stained the VA samples with a working solution (1:200) of SYBR Green I (10,000X concentrate in DMSO, Molecular Probes) for $10 \mathrm{~min}$ in the dark and then kept them at $-80^{\circ}$ until counting. We added fluorescent microspheres (FluoSpheres carboxylate modified yellow-green fluorescent microspheres; $1.0 \mu \mathrm{m}$ diameter) as an internal standard. We acquired the data in log mode and detected their signature in bivariate plots of side scatter (SSC) vs. FL1 (Green fluorescence). We processed the flow cytometry data using BD CellQuest Pro software.

Heterotrophic bacterial production (BP) and archaeal production (ArP) were measured by ${ }^{3} \mathrm{H}$ Leucine incorporation into proteins (Smith and Azam, 1992). The heterotrophic archaeal activity was measured using erythromycin to inhibit bacterial activity, as proposed by Yokokawa et al. (2012).

160 Although the specificity of erythromycin to selectively inhibit bacteria has recently been questioned for the open ocean (Frank et al. 2016), it appears to have better efficiencies (ca. 80\%) in water of higher salinity (Oren et al. 1990; Pedrós-Alió et al. 2000) and for specific functional groups as nitrifiers, particularly Firmicutes (Du et al. 2016). For each pond, two sets of three replicate (1.5 $\mathrm{ml}$ ) and two trichloroacetic-acid (TCA, 50\%)-killed (final concentration10\%) samples were incubated at in situ temperature with $54.6 \mathrm{nM}$ or $58.4 \mathrm{nM}$ leucine (1:2 hot: cold v/v) for 2 to $5 \mathrm{~h}$. One of each set of 5 
samples also contained $10 \mu \mathrm{g} \mathrm{ml}^{-1}$ of erythromycin (final concentration) to inhibit bacterial production, and obtain heterotrophic production attributed mostly to archaea. We added TCA at a final concentration of $10 \%$ to end the incubations. In the laboratory, the samples were centrifuged (15366 g for $10 \mathrm{~min}$ ), rinsed with TCA (5\%), vortexed, and centrifuged again. Finally, we added $1.5 \mathrm{ml}$ of liquid scintillation cocktail (Ecoscint A) to each sample and determined the incorporated radioactivity using an auto-calibrated scintillation counter (Beckman LS 6000 TA).

\subsection{Statistical analyses}

To determine the main drivers of the observed microbial patterns, we carried out four sets of generalized linear models (GLMs). In the first set of GLMs, the dependent microbial variables were heterotrophic prokaryotic abundance (HPA), cyanobacterial abundance (CyA), heterotrophic bacterial production (BP), and heterotrophic archaeal production (ArP). The predictor variables selected were site (i.e., each wetland complex as a categorical variable), and as continuous variables, salinity, total dissolved nitrogen (TDN), and total dissolved phosphorus (TDP). When necessary, log and square-root transformations were applied to the dependent and predictor variables to improve the fit to a normal distribution, and to avoid heteroscedasticity. In the second set of GLMs, we also included the concentration of DOC as a predictor variable but did not include the Camargue site since this variable was not measured there. In the third set of GLMs, we determined the best predictors of virus abundance (dependent variable) in the six sites (Odiel M, VPalma, CGata, SPola, Hondo, and EbroD) where this variable was available. Nutrients were not included as predictors because viruses are mostly dependent on host (bacterial or archaeal) density. We considered the study site as a categorical variable, and salinity, PA, and CyA as continuous variables. To determine the potential effect of viruses on the other microbial components, we performed the fourth set of GLMs in which VA is considered as a predictor variable and $\mathrm{BP}$ and ArP as dependent variables. We selected the model with the smallest value of the Akaike Information Criterion (AIC) as the best model for each dependent variable considered. More details of alternative models with $\triangle \mathrm{AIC}<2.0$ are in the Supplementary Tables S2-S6. All analyses were performed using Statistica 7.0 software. 


\section{Results}

The study ponds represented a wide range of environmental conditions. Salinity ranged more than four orders of magnitude, from 0.22 to $343 \mathrm{ppt}$ (Table 1), spanning oligo- to hyper-saline conditions; the highest median value was in EbroD ponds, and the lowest median value in El Hondo ponds (Fig. 2a). DOC concentrations ranged from 0.24 to 5.76 mmol-C $1^{-1}$ (Table1), with the highest median concentration in EbroD ponds (as for salinity) and the lowest in CGata ponds (Fig. 2b). TDN concentrations ranged from 0.02 to $0.62 \mathrm{mmol}^{-\mathrm{N}^{-1}}$ (Table 1), with EbroD ponds also showing the highest median TDN concentration and SPola salt pans the lowest values (Fig. 2c). TDP concentrations ranged from 0.50 to $40.09 \mu$ mol-P $~^{-1}$ (Table 1), with the highest median value at OdielM wetlands and the lowest median at CGata salt pans (Fig. 2d).

Biological variables also ranged widely. Prokaryotic heterotrophic abundances (PHA) ranged almost three orders of magnitude, from $0.35 \times 10^{6}$ to $252 \times 10^{6}$ cells ml$^{-1}$ (Supplementary Table S1), with the highest median value in Tyna salt pans and the lowest in CGata salt pans (Fig. 3a). The range in cyanobacterial abundances was even higher, ranging from 0.01 to $38105\left(\times 10^{3}\right)$ cells $\mathrm{ml}^{-1}$ (Supplementary Table S1; Fig. 3b). Heterotrophic bacterial production ranged from 19 to 3007 pmoles of leucine $1^{-1} h^{-1}$ (Supplementary Table S1; Fig. 3c) with the highest median value at SPola salt pans and the lowest at Thyna salt pans. Heterotrophic archaeal production ranged from 56 to 2290 pmoles of leucine $1^{-1} h^{-1}$ with the highest median value at EbroD ponds and the lowest at Camargue ponds.

210 (Supplementary Table S1; Fig. 3d). Chlorophyll-a concentrations ranged more than 10000-fold from 0.04 to $617.41 \mu \mathrm{g}^{-1}$ (Table1), with the highest median value at Thyna salt pans and the lowest at EbroD ponds (Fig. 3e).

In the first set of GLMs, the best model for heterotrophic prokaryotic abundance included the TDN concentration and the wetland site (categorical) as predictors (Table 2). The residuals of 215 heterotrophic prokaryotic abundance (once the site was controlled for) were significantly and positively related to TDN (Fig. 4 a). Alternative (less explanatory) models also included salinity or TDP (Table supplementary S2). The best GLM for cyanobacterial abundance included the site as a categorical variable and TDN and TDP as continuous variables, with a significant positive partial relationship with TDN and negative partial relationship with TDP (Table 2). In the case of heterotrophic bacterial 

heterotrophic bacterial production (once the site was controlled for) were significantly and negatively related to TDN (Fig. 4 b). Indeed, the higher the TDN concentration, the lower the bacterial production, irrespectively of the site. Alternative (less explanatory) models also included salinity or TDP (Supplementary Table S2). For archaeal heterotrophic production, the best GLM also included TDN and site as predictors (Table 2). In contrast to heterotrophic bacterial production, the residuals of heterotrophic archaeal production (once the site was controlled for) were significantly and positively related to TDN concentration (Fig. $4 \mathrm{c}$ ). Indeed, the higher the TDN, the higher the archaeal production, irrespective of site. Alternative (less explanatory) models also included salinity or TDP (Supplementary Table S2).

In the second set of GLMs, we also included the concentration of DOC as a predictor variable but excluded the Camargue site since these data were not available. This predictor variable only affected the results previously exposed to the heterotrophic prokaryotic abundance and the heterotrophic bacterial production (Table supplementary S3). In this second analysis, heterotrophic prokaryotic abundance was affected negatively by salinity and positively by DOC concentration, while depending on the site, DOC concentration negatively affected bacterial production.

In the third set of GLMs, we determined the best GLM for the virus abundance, excluding nutrients as predictors (Table 3). This model included salinity as a continuous predictor and site as a categorical predictor. We observed a positive relationship between the residuals of virus abundance (once the site was controlled for) and salinity (Figure 5). Alternative (less explanatory) models also

240 included heterotrophic prokaryotic and cyanobacterial abundances (Table supplementary S4).

Finally, in the fourth set of GLMs, we included viral abundance as a predictor of heterotrophic bacterial and archaeal production (Table supplementary S5), but only considered the following sites: Odiel M, VPalma, CGata, SPola, Hondo, and EbroD. The best GLM for heterotrophic bacterial production included salinity and virus abundance as predictors (Table 4). Once the site effect was controlled for, we observed a significant negative relationship between heterotrophic bacterial production and salinity (Figure 6a), as well as viral abundance (Figure 6b). On the other hand, the best GLM for heterotrophic archaeal production was coherent with the first set of GLMs, which included all 
the saline wetlands; the best GLM included TDN and site as predictors (Table supplementary S5). This result confirms the robust relationship between TDN and heterotrophic archaeal production in the study wetlands.

\section{Discussion}

The best generalized linear model (GLM), including all the coastal wetlands, indicated that the concentration of TDN positively affected the abundance of heterotrophic prokaryotes and heterotrophic archaeal production. TDN was consistently associated with greater archaeal heterotrophic production, even considering the alternative GLMs with other predictor variables, such as DOC concentration and viral abundance (VA). In contrast, TDN affected negatively heterotrophic bacterial production, but this result changed when DOC and VA were also considered as predictor variables in alternative GLMs. The negative relationship between TDN and heterotrophic bacterial production appeared to be mediated by salinity and VA. Heterotrophic bacterial production declined as salinity and viruses increased; therefore, there was a switch from heterotrophic bacterial production to heterotrophic archaeal production as salinity and VA increased. Archaea appeared to be the main microorganisms processing TDN in the most saline wetlands.

In this across-wetlands study, salinity did not directly affect heterotrophic archaeal production, whereas total dissolved nitrogen was consistently the best predictor, irrespectively of the variables considered, in the generalized linear models. Historically, archaea were associated with extreme environments, such as salterns, where salt concentrations are close to saturation (Oren, 1994, 2011; Antón et al. 1999). Now, we know that archaea occur in a wide range of environments and perform diverse functions in $\mathrm{N}$ cycling, including nitrification and denitrification (Francis et al. 2007, Offre et al. 2013). In our study, ammonia oxidation by archaea during nitrification likely is not a significant process due to the high concentrations of dissolved nitrogen in most wetlands, particularly in the Ebro Delta (Fig. 2). Ammonia-oxidizing archaea (AOA) are abundant in marine systems (Könneke et al. 2005, Wuchter et al. 2006, Lam et al. 2007), some lakes (Jiang et al. 2009), and wetlands (Sims et al. 2010). The relative contribution of AOA to ammonium oxidation is still uncertain, but they appear to dominate over ammonia-oxidizing bacteria ( $\mathrm{AOB}$ ) at low ammonium concentrations (Martens-Habbena et al. 
275 2009). Sims et al. (2010) also observed that AOA were dominant over ammonia-oxidizing bacteria (AOB) in freshwater oligotrophic wetlands.

On the other hand, our results emphasize that heterotrophic archaeal activity, measured as the uptake of $3 \mathrm{H}$-leucine, was coupled to total dissolved nitrogen concentration (Fig. 4c). Denitrification is primarily a heterotrophic, microaerophilic, or anoxic process widespread along salinity gradients, which can be done by archaea (Zumft, 1997). Coastal wetlands provide optimal conditions for archaeal denitrification due to their low oxygen concentrations, as a result of high salinities, and high concentrations of organic matter and nitrate (Seitzinger, 1988; Seitzinger et al. 2006). Furthermore, Orsi et al. (2016) demonstrated the organo-heterotrophic nature of some archaeal groups, which take up dissolved proteins. Therefore, heterotrophic archaeal metabolism via denitrification and protein assimilation affects the nitrogen cycle ameliorating eutrophication of recipient coastal systems. However, a more detailed analysis of functional genes of $\mathrm{N}$ processing, beyond heterotrophic production, is needed to quantitatively assess the contribution of archaea to nitrogen cycling in coastal wetlands.

Early works emphasized the importance of organic carbon derived from phytoplankton as a critical driver of heterotrophic prokaryotic (bacterial + archaeal) production in diverse aquatic ecosystems (e.g., Cole et al. 1988; Baines and Pace 1991; Ortega-Retuerta et al. 2008). However, in this study, we did not find difference between the best GLMs for heterotrophic archaeal production with and without the concentration of dissolved organic carbon (DOC) (Table S3). Indeed, the total pool of DOC concentration was not a predictive variable at least for heterotrophic archaeal production. In saline wetlands, extreme evapoconcentration (Batanero et al. 2017) and high loads of organic matter from freshwater inflows (Walton et al. 2015) result in high concentrations of DOC in oligo- to eusaline wetlands, likely ensuring plenty DOC for heterotrophic metabolism. Similarly, TDP was not included as a predictor variable in the best GLMs for the different microbial variables, except for the abundance of cyanobacteria (CyA). Bacterioplankton growth is assumed to be limited by the availability of phosphorus in many aquatic ecosystems (Cotner et al. 1997; Smith and Prairie 2004; Ortega-Retuerta et al. 2007). However, more recently, Cotner et al. (2010) demonstrated that bacteria exhibit high flexibility in their $\mathrm{P}$ content and stoichiometry, questioning the ranges of P-limitation. Our data suggest 
that neither phosphorus nor dissolved organic carbon appear to affect significantly the prokaryotic activity in the full range of saline wetlands studied.

In the study wetlands, heterotrophic bacterial production (BP) appeared to be controlled by viral abundance (VA) and salinity (Fig. 6), providing an indirect explanation for the negative correlation between total dissolved nitrogen and BP (Fig. 4b). The results showed that, within a given wetland complex, VA increased significantly with salinity (Table 3, Fig. 5), and negatively affected the BP (Table 4, Fig. 6b), but did not have a significant effect on heterotrophic archaeal production (Table

310 supplementary S5). These findings suggest that most of the viruses were likely bacteriophages that caused significant bacterial mortality in these extremely saline wetlands. Thus, external factors such as evaporation would trigger an increase in VA, which in turn would increase bacterial mortality, while archaeal communities would be more resilient to such changes. Guixa-Boixereu et al. (1996) observed the highest prokaryotic losses by viral lysis at the highest salinities in solar salterns. Another

315 complementary explanation is that as the salinity increases, there is a coupled decline in oxygen solubility, promoting suboxic conditions. High salinity and low oxygen may be more energetically favourable conditions for some halophilic archaeal groups (Oren, 2001).

The projected scenario of climatic warming includes wetland salinization due to sea-level rise and decreases of freshwater discharges from rivers, which will allow marine waters further into the estuaries, salinizing the surrounding wetlands (Herbert et al. 2015; Schuerch et al. 2018). Human population growth and crop production are leading to more nitrogen inputs (Mulholland et al. 2008; Mekonnen \& Hoekstra, 2015). These two environmental risks can interact, affecting the potential services of these coastal wetlands. Eutrophication can boost the mineralization of organic carbon, reducing the carbon storage capacity of coastal marshes (Deegan et al. 2012), and salinization can affect the bacterial capacity to remove nitrogen (Franklin et al. 2017). Our results imply that microbial activity will change from bacterial dominated processes to archaeal-dominated processes along with the increases of nitrogen and salinity. More studies linking the processing rates of dissolved nitrogen and organic carbon with specific archaeal taxa will allow more accurate predictions in the next scenarios of global change. 
https://doi.org/10.5194/bg-2020-60

Preprint. Discussion started: 3 April 2020

(c) Author(s) 2020. CC BY 4.0 License.

(c) (i)

\section{Conclusions}

The concentration of total dissolved nitrogen appeared to determine the abundance of heterotrophic prokaryotes and, mainly, the heterotrophic archaeal production in the suite of coastal wetlands studied. In contrast, total dissolved nitrogen affected negatively to heterotrophic bacterial production. We think

335 that this negative relationship between total dissolved nitrogen and heterotrophic bacterial production appeared to be mediated by salinity and virus abundance. Heterotrophic bacterial production declined as salinity and viruses increased; therefore, there was a switch from heterotrophic bacterial production in wetlands with lower nitrogen content and salinity to heterotrophic archaeal production in wetlands with higher nitrogen and salinity. Archaea appeared to be the main prokaryotes processing nitrogen in the

340 most saline wetlands. Therefore, changes in nitrogen inputs and salinities associated with global change can alter prokaryotic functional groups and, consequently, the ecosystem services provided by coastal wetlands.

\section{Data availability}

Additional figures and tables can be found in the supplementary information.

\section{Author contributions}

I.R., A.J.G., J.A.A., M.V. and C.A.S. designed this study; G.L.B., A.J.G., J.A.A., M.V., and I.R. performed the samplings and most of biological and chemical analysis. G.L.B. and C.A.S. analyzed the virus abundance. G.L.B., A.J.G., and I.R. analyzed the data and wrote the manuscript with input from 350 all the authors.

\section{Competing interests}

The authors declare that the research was conducted in the absence of any commercial or financial relationships that could be construed as a potential conflict of interest. 
https://doi.org/10.5194/bg-2020-60

Preprint. Discussion started: 3 April 2020

(c) Author(s) 2020. CC BY 4.0 License.

(c) (i)

\section{Acknowledgements}

This research was funded by the projects the projects FLAMENCO (CGL2010-15812) and HERA (CGL2014-52362-R) of the Spanish Ministry of Economy and Competitiveness, the Modeling Nature

360 Scientific Unit (UCE.PP2017.03), Consejería de Economía, Conocimiento, Empresas y Universidad and European Regional Development Fund (ERDF), ref. SOMM17/6109/UGR, and a PhD fellowship FPI (Formación del Personal Investigador: BES-2011-043658) from the Spanish Government to GLB. We specially thank Alejandra Fernández and Eulogio Corral for their help in the field and laboratory. We also thank the facilities and technical staff of Odiel Marshes, Veta la Palma (Doñana National Park), El

365 Hondo, Santa Pola, Ebro Delta, Tour du Valat (Camargue), Molentargius (Sardinia), and Université de Gabês (Tunisia). We also thank the logistic support of Josefa Antón at the University of Alicante, Arnaud Béchet at Tour du Valat, and M.A. Chokri and S. Selmi in the Tunisian site.

\section{References}

Álvarez-Salgado, X.A. and Miller, A.E.J.: Simultaneous determination of dissolved organic carbon and

370 total dissolved nitrogen in seawater by high temperature catalytic oxidation: conditions for precise shipboard measurements, Mar. Chem., 62, 325-333, doi: 10.1016/S0304-4203(98)00037-1, 1998.

American Public Health Association.: Standard methods for the examination of water and wastewater, APHA., 18th ed,1992.

Antón J., Llobet-Brossa, E., Rodriguez-Valera, F., and Amann, R.: Fluorescence in situ hybridization analysis of the prokaryotic community inhabiting crystallizer ponds, Environ. Microbiol., 1, 517-523, doi:10.1046/j.1462-2920.1999.00065.x, 1999.

Ardón, M., Morse, J. L., Colman, B. P., and Bernhardt, E. S.: Drought-induced saltwater incursion leads to increased wetland nitrogen export, Global Change biol., 19(10), 2976-2985, doi: 10.1111/gcb.12287, 2013. 
https://doi.org/10.5194/bg-2020-60

Preprint. Discussion started: 3 April 2020

(c) Author(s) 2020. CC BY 4.0 License.

Athearn, N. D., Takekawa, J. Y., and Shinn, J. M.: Avian response to early tidal salt marsh restoration at former commercial salt evaporation ponds in San Francisco Bay, California, USA, Nat Resour and Env Iss., 15(1), 14, 2009.

Baines, S. B., and Pace, M. L.: The production of dissolved organic matter by phytoplankton and its importance to bacteria: patterns across marine and freshwater systems, Limnol. Oceanogr., 36(6), 10781090, doi:10.4319/lo.1991.36.6.1078, 1991.

Bass-Becking, L. G. M.: Historical notes on salt and salt-manufacture, The Scientific Monthly., 32(5), 434-446, 1931.

395 Batanero, G.L., León-Palmero, E., Li, L., Green, A.J., Rendón-Martos, M., Suttle, C.A., Reche, I.: Flamingos and drought as drivers of nutrients and microbial dynamics in a saline lake, Sci. Rep., 7 (1), 12173, doi:10.1038/s41598-017-12462-9, 2017.

Battye, W., Aneja, V. P., and Schlesinger W. H.: Is nitrogen the next carbon? Earth's Future., 5, 894904, doi:10.1002/2017EF000592, 2017.

Britton, R.H., Johnson, A. R.: An ecological account of a Mediterranean salina: The Salin de Giraud, Camargue (S. France). Biological Conservation, 42, 185-230, 1987.

405 Brunet, R. C., \& Garcia-Gil, L. J.: Sulfide-induced dissimilatory nitrate reduction to ammonia in anaerobic freshwater sediments, FEMS Microbiol. Ecol., 21(2), 131-138, doi: 10.1111/j.15746941.1996.tb00340.x, 1996. 
https://doi.org/10.5194/bg-2020-60

Preprint. Discussion started: 3 April 2020

(c) Author(s) 2020. CC BY 4.0 License.

Brussaard, C. P. D., Payet, J. P., Winter, C., and Weinbauer, M. G.: Quantification of aquatic viruses by 410 flow cytometry. Manual of Aquatic Viral Ecol. (ed. Wilhelm, S. W., Weinbauer, M. G. Suttle C. A.), 11, 102-109, doi: 10.4319/mave.2010.978-0-9845591-0-7.102, 2010.

Canfield, D. E., Glazer, A. N., and Falkowski, P. G.: The evolution and future of earth's nitrogen cycle, Sci., 330, 192-196. doi: 10.1126/science.1186120, 2010.

415

Casamayor, E. O., Massana, R., Benlloch, S., Ovreas, L., Diez, B., Goddard, V. J., Gasol, J. M., Joint, I., Rodriguez-Valera, F., and Pedros-Alio, C.: Changes in archaeal, bacterial and eukaryal assemblages along a salinity gradient by comparison of genetic fingerprinting methods in a multi- pond solar saltern., Environ. Microbiol., 4:338-348, doi: 10.1046/j.1462-2920.2002.00297.x, 2002.

Chmura, G., and Anisfeld, S., Donald C., and Lynch, J.C.: (2003). Global carbon sequestration in tidal, saline wetland soils, Global Biogeochem. Cycles., 17(4), 1111, doi: 10.1029/2002GB001917, 2003.

Cole, J. J., Findlay, S., and Pace, M. L.: Bacterial production in fresh and saltwater ecosystems: a crosssystem overview, Mar. ecol. Prog. ser., 43(1), 1-10, 1988.

Cotner, J. B., Ammerman, J. W., Peele, E. R., and Bentzen, E.: Phosphorus-limited bacterioplankton growth in the Sargasso Sea, Aquatic Microbial Ecology., 13(2), 141-149, doi: 10.3354/ame013141, 1997.

Cotner, J.B., Hall, E.K., Scott, J.T., Heldal, M.: Freshwater bacteria are stoichiometrically flexible with a nutrient composition similar to seston, Front Microbiol., 1: 132, doi: 10.3389/fmicb.2010.00132, 2010.

435 Deegan, L., Johnson, D., Warren, R. et al. Coastal eutrophication as a driver of salt marsh loss. Nature 490: 388-392. doi: 10.1038/nature11533, 2012. 
https://doi.org/10.5194/bg-2020-60

Preprint. Discussion started: 3 April 2020

(c) Author(s) 2020. CC BY 4.0 License.

DeLong, E. F.: Archaea in coastal marine environments, Proc. Natl. Acad. Sci. USA., 89:5685-5689, doi: 10.1073/pnas.89.12.5685, 1992.

440

Du, J., Qi, W., Niu, Q., Hu, Y., Zhang, Y., Yang, M., and Li, Y. Y.: Inhibition and acclimation of nitrifiers exposed to erythromycin. Ecological engineering, 94, 337-343, 2016.

Francis, C. A., Beman, J. M., and Kuypers, M. M.: New processes and players in the nitrogen cycle:

445 The microbial ecology of anaerobic and archaeal ammonia oxidation, ISME J., 1, 19-27, doi: 10.1038/ismej.2007.8, 2007.

Frank, A. H., Pontiller, B., Herndl, G. J., and Reinthaler, T.: Erythromycin and GC7 fail as domainspecific inhibitors for bacterial and archaeal activity in the open ocean, Aquat. Microb. Ecol., 77(2), 99110, doi: 10.3354/ame01792, 2016.

Franklin, R.B., Morrissey, E.M., Morina, J.C.: Changes in abundance and community structure of nitrate-reducing bacteria along a salinity gradient in tidal wetlands, Pedobiologia., 60, 21-26., doi: 10.1016/j.pedobi.2016.12.002, 2017.

Fuhrman, J. A., K. McCallum, and A. A. Davis.: Novel major archae-bacterial group from marine plankton, Nature., 356:148-149, doi: 10.1038/356148a0, 1992.

García-Vargas, E. A., and Martínez Maganto, J.: La sal de la Bética romana: Algunas notas sobre su 460 producción y comercio. Habis, 37, 253-274, 2006.

Gasol J., Casamayor E., Join I., Garde K., Gustavson K., Benlloch S., Diez, B., Schauer, M., Massana, R., Pedrós-Alio, C.: Control of heterotrophic prokaryotic abundance and growth rate in hypersaline planktonic environments, Aquat Microb Ecol., 34: 193-206, doi: 10.3354/ame034193, 2004. 
https://doi.org/10.5194/bg-2020-60

Preprint. Discussion started: 3 April 2020

(c) Author(s) 2020. CC BY 4.0 License.

(c) (i)

465

Gasol J., del Giorgio, P.: Using flow cytometry for counting natural planktonic bacteria and understanding the structure of planktonic bacterial communities, Scientia Marina., 64:197-224, doi :10.3989/scimar.2000.64n2197, 2000.

470 Geertz-Hansen, O., Montes, C., Duarte, C., Sand-Jesen, K., Marba, N., Grillas, P.: Ecosystem metabolism in a temporary Mediterranean marsh (Doñana National Park, SW Spain), Biogeosciences 8., doi: 10.5194/bg-8-963-2011, 2011.

Ghai R., Pašić L., Fernández A. B., Martin-Cuadrado A.-B., Megumi Mizuno C., McMahon K. D., 475 Papke R. T., Stepanauskas R., Rodriguez-Brito B., Rohwer, F., Sánchez-Porro, C., Ventosa, A., Rodríguez-Valera, F.: New abundant microbial groups in aquatic hypersaline environments, Sci Rep., 1: 135, doi: 10.1038/srep00135, 2011.

Gruber, N., and Galloway, J.: An Earth-system perspective of the global nitrogen cycle, Nature., 451. 480 293-6, doi:10.1038/nature06592, 2008.

Guixa-Boixereu, N., Calderon-Paz, J.I., Heldal, M., Bratbak, G., and Pedrós-Alió C.: Viral lysis and bacterivory as prokaryotic loss factors along a salinity gradient. Aquat. Microb. Ecol. 11, 215227, doi:10.3354/ame011215, 1996.

485

Hahn, M.W.: The microbial diversity of inland waters, Cur. Op. Biotechnol., 17: 256-261, doi: 10.1016/j.copbio.2006.05.006, 2006.

Herbert, E.R., P. Boon, A.J. Burgin, S.C., Neubauer, R.B. ,Franklin, M., Ardón, K.N., Hopfensperger, 490 L.P.M., Lamers., and Gell, P.: A global perspective on wetland salinization: Ecological consequences of a growing threat to freshwater wetlands, Ecosphere., 6(10):206, doi: 0.1890/ES14-00534, 2015. 
https://doi.org/10.5194/bg-2020-60

Preprint. Discussion started: 3 April 2020

(c) Author(s) 2020. CC BY 4.0 License.

Herndl, G.J., Reinthaler, T., Teira, E., van Aken H., Veth C., Pernthaler A., and Pernthaler J.: Contribution of archaea to total prokaryotic production in the deep atlantic ocean, Appl Environ 495 Microbiol., 71: 2303-2309, doi: 10.1128/AEM.71.5.2303-2309, 2005.

Ingalls, A.E., Shah, S.R., Hansman, R.L., Aluwihare, L.I., Santos, G.M., Druffel, E.R.M., Perason, A.: Quantifying archaeal community autotrophy in the mesopelagic ocean using natural radiocarbon, Proc Natl Acad Sci USA., 103: 6442-6447, doi: 10.1073/pnas.0510157103, 2006.

Jeppesen, E., Brucet, S., Naselli-Flores, L., Papastergiadou, E., Stefanidis, K., Noges, T., Noges, P., Attayde, J.L., Zohary, T., Coppens, J., Bucak, T., Menezes, R.F., Freitas, F.R.S., Kernan, M., Sondergaard, M., Beklioglu, M.: Ecological impacts of global warming and water abstraction on lakes and reservoirs due to changes in water level and related changes in salinity, Hydrobiologia., 750, 201227, doi:10.1007/s10750-014-2169-x, 2015.

Jiang, H., Dong, H., Yu, B., Lv, G., Deng, S., Berzins, N., Dai M.: Diversity and abundance of ammoniaoxidizing archaea and bacteria in Qinghai Lake, Northwestern China, Geomicrobiol J., 26(3):199-211, doi: 10.1080/01490450902744004, 2009.

510

Justice, NB., Pan, C., Mueller, R., Spaulding, SE., Shah, V., Sun, C.L., Yelton, A.P., Miller, C.S., Thomas, B.C., Shah, M., VerBerkmoes, N., Hettich, R., Banfield, J.F.: Heterotrophic archaea contribute to carbon cycling in low-pH, suboxic biofilm communities, Appl Environ Microbiol., 78: 8321-8330, doi: 10.1128/AEM.01938-12, 2012.

Karner, M., E. F. DeLong, and D. M. Karl.: Archaeal dominance in the mesopelagic zone of the Pacific Ocean, Nature., 409:507-509, doi: 10.1038/35054051,2001. 
https://doi.org/10.5194/bg-2020-60

Preprint. Discussion started: 3 April 2020

(c) Author(s) 2020. CC BY 4.0 License.

Könneke, M., Bernhard, A.E., de la Torre, J.R.,Walker, C.B.,Waterbury, J.B., Stahl, D.A.: Isolation of 520 an autotrophic ammonia-oxidizing marine archaeon, Nature., 437:543-46, doi: 10.1038/nature0391, 2005.

Lam, P., Jensen, M.M., Lavik, G., McGinnis, D.F., Muller, B., Schubert, C.J., Amann, R., Thamdrup, B., Kuypers, M.M.M.: Linking crenarchaeal and bacterial nitrification to anammox in the Black Sea,

525 Proc. Natil. Acad. Sci. USA,. 104 (17), 7104e7109, doi: 10.1073/pnas.0611081104, 2007.

Lamers, L.P.M., Tomassen, H.B.M., Roelofs, J.G.M.: Sulfate-induced entrophication and phytotoxicity in freshwater wetlands, Environ. Sci.\& Technol., 32, 199-205, doi: 10.1021/es970362f, 1998.

530 Laverman, A. M., Canavan, R. W., Slomp, C. P., and Van Cappellen, P.: Potential nitrate removal in a coastal freshwater sediment (Haringvliet Lake, The Netherlands) and response to salinization, Water Res., 41(14), 3061-3068, doi: 10.1016/j.watres.2007.04.002, 2007.

Lazar, C.S., Baker, B.J., Seitz, K., Hyde, A.S., Dick, G.J., Hinrichs, K.U., Teske, A.P.:Genomic 535 evidence for distinct carbon substrate preferences and ecological niches of Bathyarchaeota in estuarine sediments, Environ Microbiol., 18: 1200-1211, doi: 10.1111/1462-2920.13142, 2016.

Luo, M., Huang, J. F., Zhu, W. F., \& Tong, C.: Impacts of increasing salinity and inundation on rates and pathways of organic carbon mineralization in tidal wetlands: a review, Hydrobiologia., 827(1), 3149, doi: 10.1007/s10750-017-3416-8, 2019.

Martens-Habbena, W., Berube, P.M., Urakawa, H., de la Torre, J.R., Stahl, D.A.: Ammonia oxidation kinetics determine niche separation of nitrifying Archaea and Bacteria, Nature., 461: 976-79, doi: 10.1038/nature08465, 2009. 
https://doi.org/10.5194/bg-2020-60

Preprint. Discussion started: 3 April 2020

(c) Author(s) 2020. CC BY 4.0 License.

Mekonnen, M.M., Hoekstra, A.Y.:Global Gray Water Footprint and Water Pollution Levels Related to Anthropogenic Nitrogen Loads to Fresh Water. Environ. Sci.Technol., 49, 12860-12868, doi: 10.1021/acs.est.5b03191, 2015.

550 Mitsch, W., Bernal, B., and Hernández, M.: Ecosystem services of wetlands. International Journal of biodiversity Science, Int. J. Biodivers. Sci. Ecosyst. Serv. Manage., 11(1): 1-4, doi: 0.1080/21513732.2015.1006250, 2015.

Mitsch, W., and G., Gosselink, J.: The Value of Wetlands: Importance of Scale and Landscape Setting, 555 Ecol. Econ., 35. 25-33, doi: 10.1016/S0921-8009(00)00165-8, 2000.

Mulholland, P. J., Helton, A. M., Poole, G. C., Hall, R. O., Hamilton, S. K., Peterson, B. J., and Dodds, W. K.: Stream denitrification across biomes and its response to anthropogenic nitrate loading, Nature., 452(7184), 202, doi: 10.1038/nature06686, 2008.

560

Murphy, J., and Riley, J. P.: A modified single solution method for the determination of phosphate in natural waters, Analytica Chimica Acta., 27, 31-36. Rev. Sci. Eau, 15, 123-135, 1962.

Offre, A., Spang., Schleper, C.: Archaea in biogeochemical cycles, Annu. Rev. Microbiol., 67 pp. $437-$ 565 457, doi: 10.1146/annurev-micro-092412-155614, 2013.

Oren, A.: The use of protein synthesis inhibitors in the estimation of the contribution of halophilic archaebacteria to bacterial activity in hypersaline environments. FEMS Microbiology Ecology, 6, 187192, 1990.

570

Oren, A.: The ecology of the extremely halophilic archaea, FEMS Microbiol Rev.,13, 415-440, doi: 10.1016/0168-6445(94)90063-9, 1994. 
https://doi.org/10.5194/bg-2020-60

Preprint. Discussion started: 3 April 2020

(c) Author(s) 2020. CC BY 4.0 License.

(c) (i)

Oren, A.: The bioenergetic basis for the decrease in metabolic diversity at increasing salt 575 concentrations: implications for the functioning of salt lake ecosystems, Hydrobiologia., 466:61-72, doi: 10.1023/A:101455711, 2001.

Oren A.: Ecology of halophiles, Extremophile Handbook (Horikoshi K ed), Springer, Tokyo., 343-361, doi: 10.1007/978-4-431-53898-1_16, 2011.

580

Orsi, R.H., Wiedmann, M.: Characteristics and distribution of Listeria spp., including Listeria species newly described since 2009, Appl. Microbiol. Biotechnol., 100, 5273-5287, doi: 10.1007/s00253-0167552-2, 2016.

585 Ortega-Retuerta, E., Pulido-Villena, E., and Reche, I.: Effects of Dissolved Organic Matter Photoproducts and Mineral Nutrient Supply on Bacterial Growth in Mediterranean Inland Waters, Micro. Ecol., 54 (1): 161-169, doi: 10.1007/s00248-006-9186-x, 2007.

Ortega-Retuerta, E., Reche, I., Pulido-Villena, E., Agustí, S., \& Duarte, C. M.: Exploring the 590 relationship between active bacterioplankton and phytoplankton in the Southern Ocean, Aquat. Micro. Ecol., 52(1), 99-106, doi: 10.3354/ame01216, 2008.

Pedrós-Alió, C., Calderón-Paz, J.I., MacLean, M.H. Medina, G., Marrasé, C., Gasol, J.M., GuixaBoixereu, N.: The microbial food web along salinity gradients, FEMS Microbiol, 10.1111/j.1574595 6941.2000.tb00708.x, 2000.

Razinkovas-Baziukas, A., Povilanskas, R.: Introducing transitional waters. In:Respiration in Aquatic systems, Oxford University Press., pp 83-102, doi: 10.1093/acprof:oso/9780198527084.003.0004, 2012.

600 
https://doi.org/10.5194/bg-2020-60

Preprint. Discussion started: 3 April 2020

(c) Author(s) 2020. CC BY 4.0 License.

(c) (i)

Roehm, C. L.: Respiration in wetland ecosystems, Respiration in Aquatic Ecosystems, eds P. A. del Giorgio and P. J. Williams (New York, NY: Oxford University Press)., 83-102, 2005.

Sánchez, M.I., Green, A.J., and Castellanos, E.M. (2006) Temporal and spatial variation of an aquatic 605 invertebrate community subjected to avian predation at the Odiel salt pans (SW Spain). Archiv Fur Hydrobiologie, 166, 199-223.

Saunders, D.L., and Kalff J.: Nitrogen retention in wetlands, lakes and rivers, Hydrobiology., 443. 205212, doi: 10.1023/A:1017506914063, 2001.

610

Schlesinger, W.: On the Fate Anthropogenic Nitrogen. Proceedings of the National Academy of Sciences of the United States of America. 106. 203-8, doi:.1073/pnas.0810193105, 2009.

Schuerch, M., Spencer, T., Temmerman, S., Kirwan, M. L., Wolff, C., Lincke, D., McOwen, 615 C.J, Pickering, M.D., Reef, R., Vafeidis, A.T., Hinkel, J., Nicholls, R.J., and Brown, S.: Future response of global coastal wetlands to sea-level rise, Nature.,561, 231-234. doi: 10.1038/s41586-0180476-5, 2018.

Seitzinger, S.P.: Denitrification in freshwater and coastal marine ecosystems Ecological and 620 geochemical significance, Limnol.Oceanogr., 33, 702-724, doi: 10.4319/lo.1988.33.4part2.0702, 1988.

Seitzinger, S.P., and Harrison, J., and Bohlke, J. and Bouwman, A., and Lowrance, R., and Peterson, B., and Tobias, C., and Drecht, G.: Denitrification Across Landscapes and Waterscapes: A Synthesis. Ecol. appl: a publication of the Ecol. Soc. of Am, 16. 2064-90, doi: 10.1890/1051625 0761(2006)016[2064:DALAWA]2.0.CO;2, 2007. 
https://doi.org/10.5194/bg-2020-60

Preprint. Discussion started: 3 April 2020

(c) Author(s) 2020. CC BY 4.0 License.

Sims, A., Horton, J., Gajaraj, S., McIntosh, S., Miles, R.J., Mueller, R., Reed, R., Hu, Z.: Temporal and spatial distributions of ammonia-oxidizing archaea and bacteria and their ratio as an indicator of oligotrophic conditions in natural wetlands, Water Res., 46 (13), 4121e4129, 2012.

630

Smith, D.C and Azam, F.: A simple, economical method for measuring bacterial protein synthesis rates in seawater using 3H-leucine, Mar Microb Food Webs., 6:107-114, 1992.

Smith, E. M., and Prairie, Y. T.: Bacterial metabolism and growth efficiency in lakes: the importance of 635 phosphorus availability, Limnol. Oceanogr., 49(1), 137-147, doi: 10.4319/1o.2004.49.1.0137, 2004.

Verhoeven, J.T.A., Arheimer, B., Yin, C.Q., Hefting, M.M.: Regional and global concerns over wetlands and water quality, Trends Ecol Evol., 21: 96-103, doi: 10.1016/j.tree.2005.11.015, 2006.

640 Walton, M.E.M., Vilas, C., Canavate, P., Gonzalez-Ortegon, E., Prieto, A., van Bergeijk, S.A., Green, A.J., Librero, M., Mazuelos, N., Le Vay, L.: A model for the future: Ecosystem services provided by the aquaculture activities of Veta la Palma, Southern Spain, Aquaculture., 448, 382-390, doi: 10.1016/j.aquaculture.2015.06.017, 2015.

645 Weston, N. B., Dixon, R. E., \& Joye, S. B.: Ramifications of increased salinity in tidal freshwater sediments: Geochemistry and microbial pathways of organic matter mineralization. J. Geophys. ResBiogeo., 111(G1), doi: 10.1029/2005JG000071, 2006.

Weston, N. B., Vile, M. A., Neubauer, D. C. and Velinsky, D. J.: Accelerated microbial organic matter 650 mineralization following salt-water intrusion into tidal freshwater marsh soils, Biogeochemistry., 102, 135-151, doi: 10.1007/s10533-010-9427-4, 2011. 
https://doi.org/10.5194/bg-2020-60

Preprint. Discussion started: 3 April 2020

(c) Author(s) 2020. CC BY 4.0 License.

(c) (i)

Wuchter, C., Abbas, B., Coolen, M.J.L., Herfort, L., van Bleijswijk, J., Timmers, P., Strous, M., Teira, E., Herndl, G.J., Middelburg, J.J., Schouten, S., Damste, J.S.S.: Archaeal nitrification in the ocean, 655 Proc. Natl. Acad. Sci.USA., 103 (33), 12317e12322, doi: 10.1073/pnas.0600756103, 2006.

Yokokawa, T., Sintes, E., De Corte, D., Olbrich, K., and Herndl, G.J.: Differentiating leucine incorporation of Archaea and Bacteria throughout the water column of the eastern Atlantic using metabolic inhibitors. Aquat. Microb. ecol. Vol. 66: 247-256. doi: 10.3354/ame01575, 2012.

660

You, J., Das, A., Dolan, E.M., Hu, Z.: Ammonia-oxidizing archaea involved in nitrogen removal. Water Res., 43 (7), 1801e1809, doi: 10.1016/j.watres.2009.01.016, 2009.

Zumft, W.G.: Cell biology and molecular basis of denitrification. Microbiol Mol Biol Rev., 61: 533$665616,1997$. 

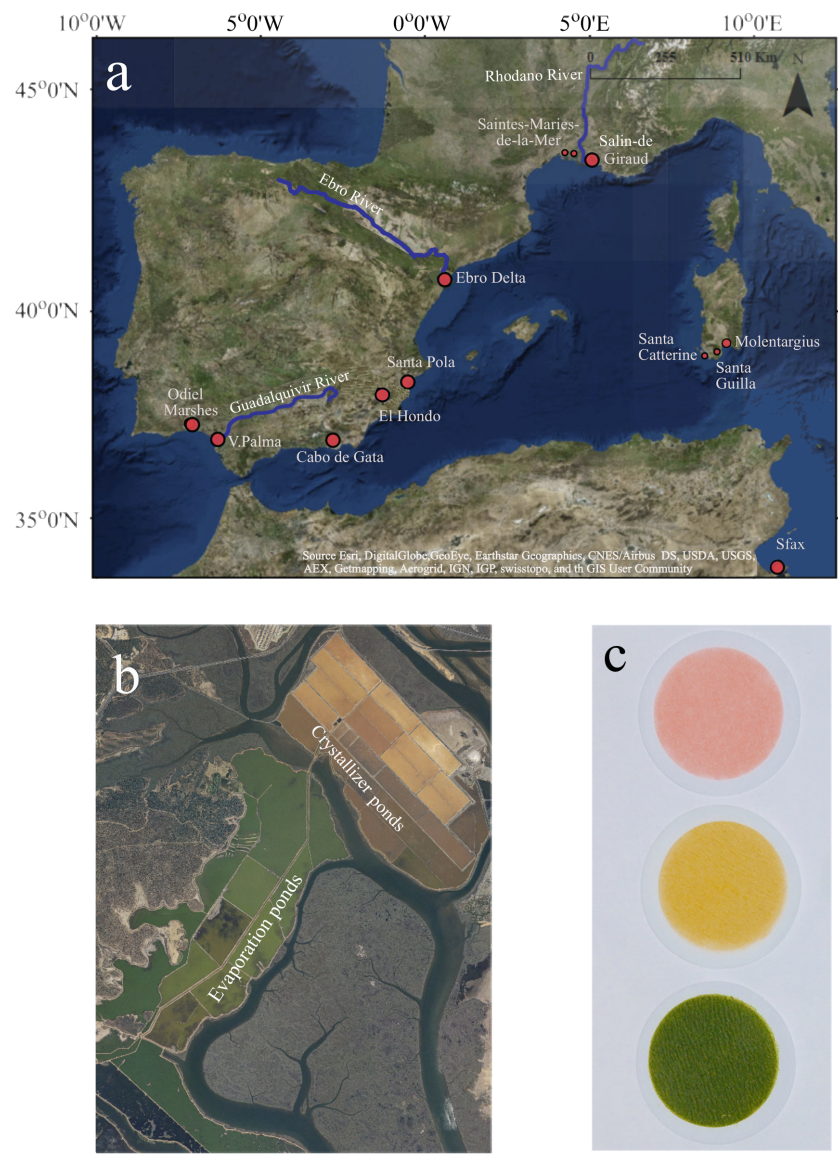

670 Figure 1. Map obtained using ArcGIS including the locations of the coastal wetlands studied (a): Odiel marshes (OdielM), Veta la Palma, (VPalma), Cabo de Gata (CGata), Santa Pola (SPola), El Hondo (Hondo), Ebro Delta (EbroD), Salin-deGiraud and Saintes-Maries-de-la-Mer (Camargue), Molentargius, Santa Guilla and Santa Catterine (Sardinia), and Sfax (Sfax). Imagery map credit: Esri, DigitalGlobe, Earthstar Geographics, CNES/Airbus DS, GeoEye, USDA FSA, USGS, Aerogrid, IGN, IGP, and the GIS User Community. (b) Orthophoto of the Odiel marshes including evaporation and

675 crystallization ponds; Orthophoto credit: Junta de Andalucía. Consejería de Agricultura, Ganadería, Pesca y Desarrollo Sostenible (ámbito de Desarrollo Sostenible). http://www.juntadeandalucia.es/medioambiente/site/rediam/ (c) G/F glass-fiber filters illustrating the pigment diversity of these ponds. 
https://doi.org/10.5194/bg-2020-60

Preprint. Discussion started: 3 April 2020

(c) Author(s) 2020. CC BY 4.0 License.

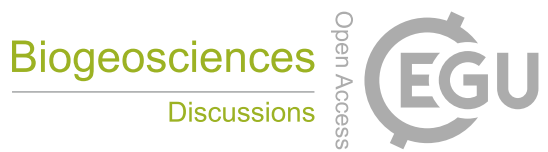

(c) (i)

a

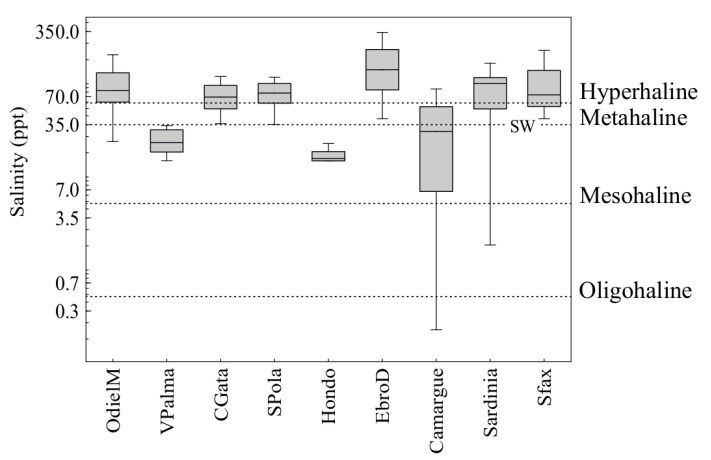

$\mathrm{b}$

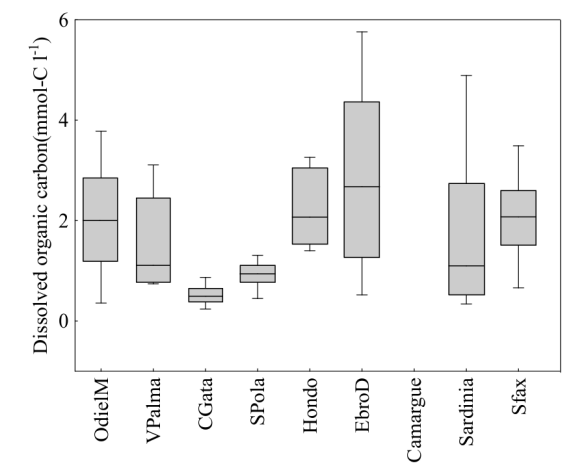

$\mathrm{C}$

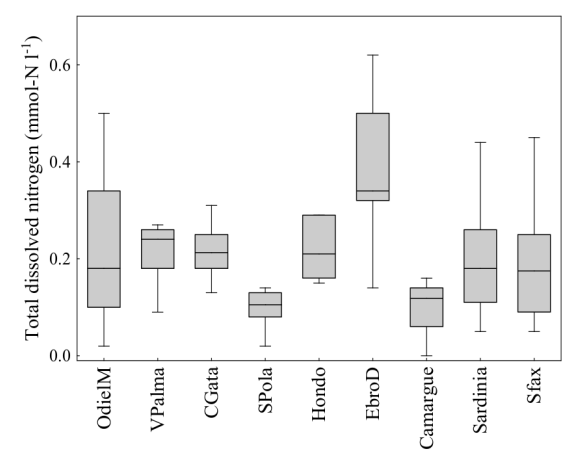

d

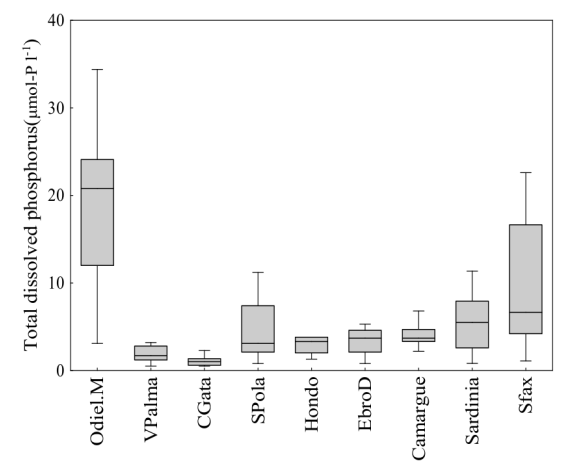

680

Figure 2. Summary of raw data for physico-chemical parameters in the western Mediterranean basin, showing salinity (a), total dissolved organic carbon (b), total dissolved nitrogen (c) and total dissolved phosphorus (d) for each saline wetland studied. Lines $=$ Median values. Boxes $=25 \%$ and $75 \%$ percentiles and whiskers $=$ non-outlier range. Outliers are shown as 685 dots and extreme points as asterisks. 


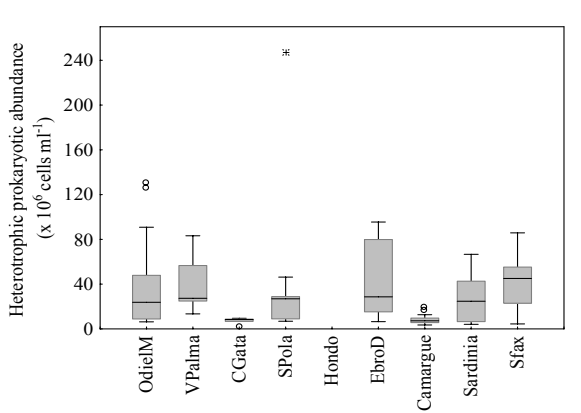

b
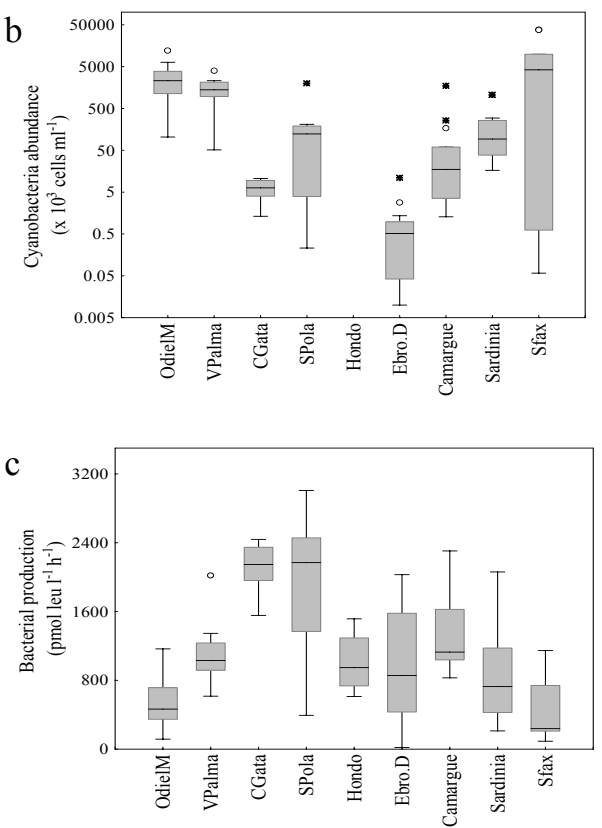

d

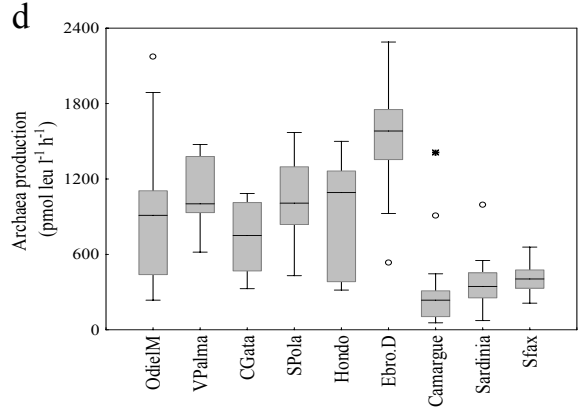

e

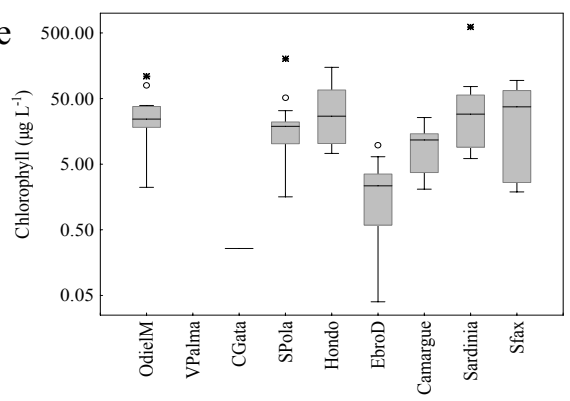

690

Figure 3. Summary of raw abundance and production of heterotrophic prokaryotes and cyanobacteria in the western Mediterranean basin, showing heterotrophic prokaryotic abundance (a), cyanobacteria abundance (b), bacterial production (c), archaea production (d) and chlorophyll concentration (e) for each saline wetland studied. Lines = Median values. Boxes 695 $=25 \%$ and $75 \%$ percentiles and whiskers $=$ non-outlier range. Outliers are shown as dots and extreme points as asterisks. 
https://doi.org/10.5194/bg-2020-60

Preprint. Discussion started: 3 April 2020

(c) Author(s) 2020. CC BY 4.0 License.

$\mathrm{a}$

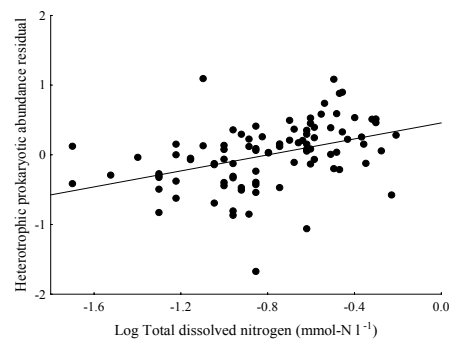

$\mathrm{b}$

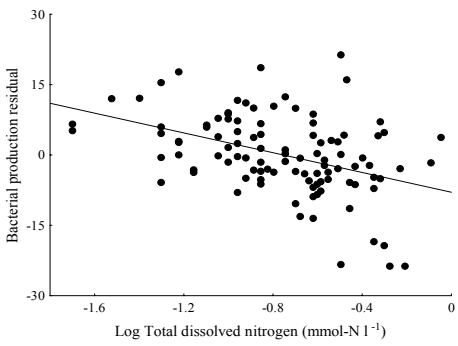

c

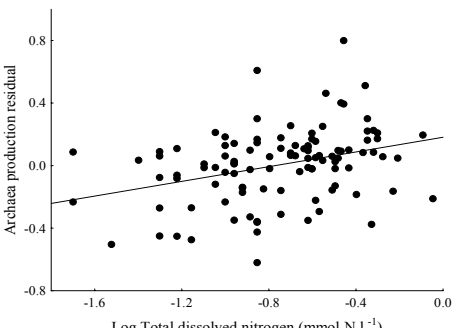

Figure 4. Linear regressions between heterotrophic abundance and prokaryotic production and total dissolved nitrogen 705 (TDN). Partial effects are presented for relationships between (a) heterotrophic prokaryotic abundance, (b) bacterial production and (c) archaea production and TDN, based on the best models shown in Table 2. In each case the Y variable represents the residuals taken from the selected model after fitting the other predictor variables. 
https://doi.org/10.5194/bg-2020-60

Preprint. Discussion started: 3 April 2020

(c) Author(s) 2020. CC BY 4.0 License.

(c) (i)

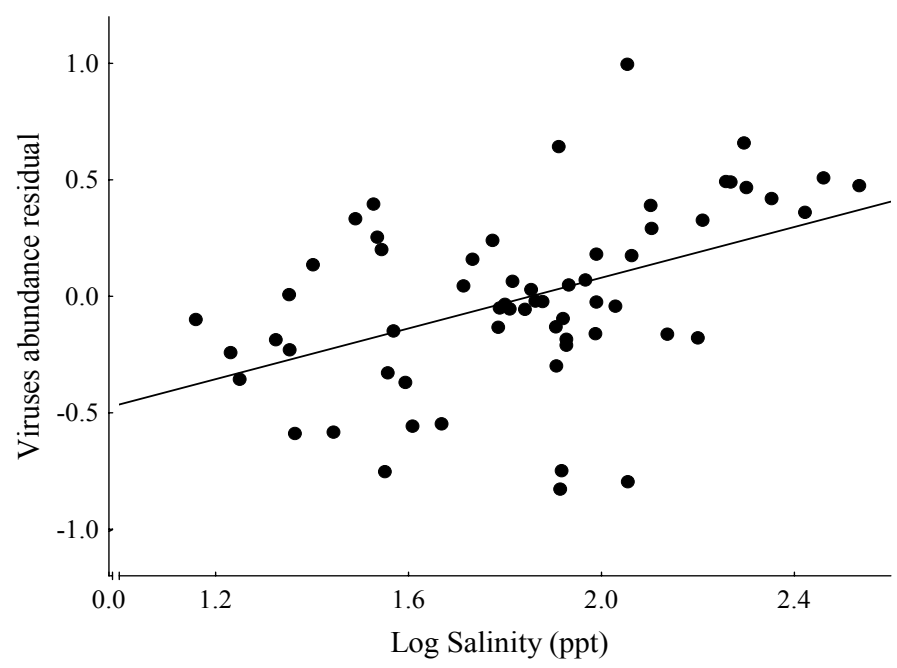

Figure 5. Partial effect for relationship between virus abundance and salinity based on the best models shown in Table 3 . 
https://doi.org/10.5194/bg-2020-60

Preprint. Discussion started: 3 April 2020

(c) Author(s) 2020. CC BY 4.0 License.

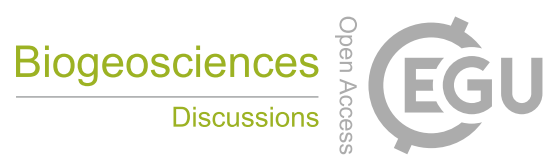

715

a

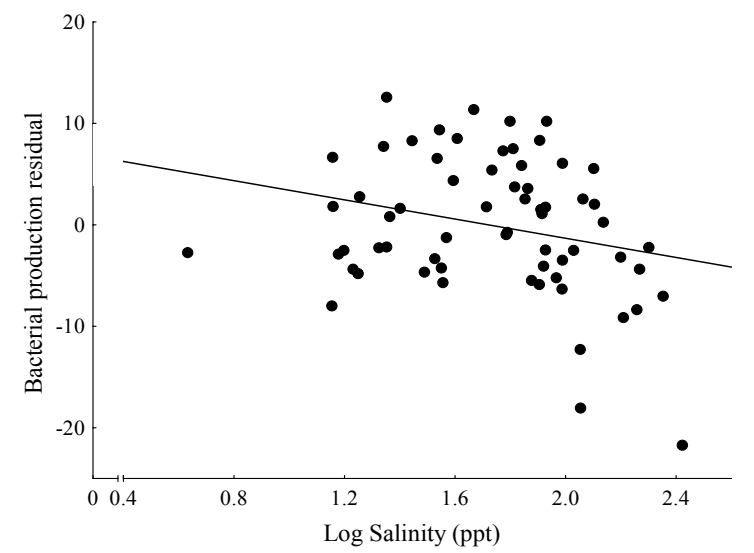

b

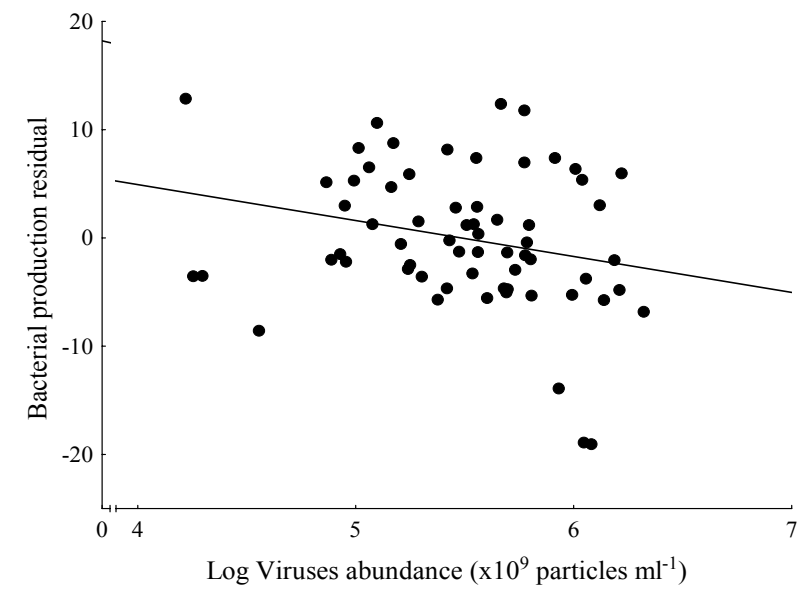

Figure 6. Linear regressions between bacterial production and their biological and physico-chemical predictors. Partial effects are shown for relationships between (a) salinity (b) virus abundance, based on the best models shown in Table 4. In each case the $\mathrm{Y}$ variable represents the residuals taken from the selected model after fitting the other predictor variables. 
https://doi.org/10.5194/bg-2020-60

Preprint. Discussion started: 3 April 2020

Table 1. Ranges of the basic physicochemical variables, total dissolved nitrogen (TDN), total dissolved phosphorus (TDP), dissolved organic carbon (DOC), concentration of chlorophyll- $a(\mathrm{Chl}-a)$ and virus abundance (VA) for each set of ponds in the study wetlands. The complete data set is in the Supplementary Table S1.

\begin{tabular}{|c|c|c|c|c|c|c|c|c|}
\hline Location Sites (acronyms) & $\mathrm{N}^{\mathrm{o}}$ Ponds & $\begin{array}{l}\text { Temperature } \\
\left({ }^{\circ} \mathrm{C}\right)\end{array}$ & $\begin{array}{l}\text { Salinity } \\
\text { (ppt) }\end{array}$ & $\begin{array}{c}\text { TDN } \\
\left(\mathrm{mmol}^{-} \mathrm{N} \mathrm{l}^{-1}\right)\end{array}$ & $\begin{array}{c}\text { TDP } \\
\left(\mu \mathrm{mol}-\mathrm{P} \mathrm{l}^{-1}\right)\end{array}$ & $\begin{array}{c}\text { DOC } \\
\left(\mathrm{mmol}^{\left.-\mathrm{C} \mathrm{l}^{-1}\right)}\right.\end{array}$ & $\begin{array}{l}\text { Chla } \\
\left(\mu \mathrm{g} 1^{-1}\right)\end{array}$ & $\begin{array}{c}\mathrm{VA} \\
\left(\mathrm{x} 10^{9}\right. \\
\left.\text { particles } \mathrm{ml}^{-1}\right)\end{array}$ \\
\hline $\begin{array}{l}\text { Odiel Marshes (OdielM) } \\
\text { Huelva, Spain }\end{array}$ & 19 & $20.1-25.4$ & $23.1-197.8$ & $0.02-0.50$ & $3.12-48.06$ & $0.36-3.78$ & $2.22-108.99$ & $0.17-3.07$ \\
\hline $\begin{array}{l}\text { Veta la Palma, Doñana } \\
\text { (VPalma) } \\
\text { Sevilla, Spain }\end{array}$ & 10 & $27-33.5$ & $14.4-34.3$ & $0.09-0.27$ & $0.51-12.27$ & $0.74-3.11$ & n.d. & $0.2-1.14$ \\
\hline $\begin{array}{l}\text { Cabo de Gata (CGata) } \\
\text { Almeria, Spain }\end{array}$ & 6 & $24.9-27.6$ & $36.1-115.6$ & $0.13-0.31$ & $0.51-2.28$ & $0.24-0.87$ & n.d. & $0.04-0.12$ \\
\hline $\begin{array}{l}\text { Santa Pola (SPola) } \\
\text { Alicante, Spain }\end{array}$ & 14 & $22-27.3$ & $35.1-162.1$ & $0.02-0.32$ & $0.81-11.22$ & $0.45-2.91$ & $1.59-201.83$ & $0.02-1.11$ \\
\hline $\begin{array}{l}\text { El Hondo (Hondo) } \\
\text { Alicante, Spain }\end{array}$ & 7 & $24.2-30.6$ & $4.3-22.0$ & $0.15-0.29$ & $1.31-8.96$ & $1.4-3.26$ & $7.3-149.63$ & $0.35-1.10$ \\
\hline $\begin{array}{l}\text { Ebro Delta (EbroD) } \\
\text { Tarragona, (Spain) }\end{array}$ & 13 & $23.8-32.9$ & $40.6-343$ & $0.14-0.62$ & $0.81-5.35$ & $0.52-5.76$ & 0.04- 9.7 & $0.09-1.69$ \\
\hline $\begin{array}{l}\text { Salin-de-Giraud, Saintes- } \\
\text { Maries-de-la-Mer } \\
\text { (Camargue), France }\end{array}$ & 14 & $19.1-30.3$ & $0.2-194.7$ & $0.04-0.35$ & $2.22-6.89$ & n.d. & $2.08-25.69$ & n.d. \\
\hline $\begin{array}{l}\text { Molentargius, Santa } \\
\text { Guilla and Santa Caterina } \\
\text { (Sardinia), Italy }\end{array}$ & 13 & $25.4-33.4$ & $2.0-238.8$ & $0.05-0.44$ & $0.81-11.35$ & $0.34-4.89$ & $6.09-617.41$ & n.d. \\
\hline $\begin{array}{l}\text { Sfax (Sfax) } \\
\text { Sfax, (Tunisia) }\end{array}$ & 12 & $24.5-29.8$ & $40.6-220.2$ & $0.05-0.45$ & $2.67-40.94$ & $0.41-3.49$ & $1.89-94.58$ & n.d. \\
\hline
\end{tabular}


Table 2. Summary of the best-generalized linear models (GLMs) (according to AIC) selected for the prokaryotic abundance and heterotrophic production. Columns show the estimates, standard errors, Wald statistic and $\mathrm{P}$ values for the selected predictor variables. The complete set of alternative (less explanatory) models with $\delta \mathrm{AIC}<2.0$ are shown (Supplementary Table S2).

\begin{tabular}{|c|c|c|c|c|c|}
\hline $\begin{array}{l}\text { Dependent } \\
\text { Variables }\end{array}$ & $\begin{array}{l}\text { Predictor } \\
\text { Variables }\end{array}$ & Estimate & $\begin{array}{c}\text { Standard } \\
\text { Error }\end{array}$ & $\begin{array}{l}\text { Wald } \\
\text { Stat. }\end{array}$ & p-values \\
\hline \multirow{3}{*}{$\begin{array}{l}\text { Prokaryotic } \\
\text { heterotrophic } \\
\text { abundance }\end{array}$} & Intercept & 2.068672 & 0.013074 & 25035.27 & 0.000000 \\
\hline & TDN & 0.109782 & 0.015932 & 47.48 & 0.000000 \\
\hline & Site & --- & --- & 43.76 & 0,000000 \\
\hline \multirow{4}{*}{$\begin{array}{c}\text { Cyanobacteria } \\
\text { abundance }\end{array}$} & Intercept & 1.799727 & 0.105138 & 293.0189 & 0.000000 \\
\hline & Site & --- & --- & 106.1193 & 0.000000 \\
\hline & TDP & -0.267744 & 0.080808 & 10.9782 & 0.000922 \\
\hline & TDN & 0.181139 & 0.087963 & 4.2406 & 0.039468 \\
\hline \multirow{3}{*}{$\begin{array}{c}\text { Heterotrophic } \\
\text { Bacterial } \\
\text { production }\end{array}$} & Intercept & 3.044352 & 0.075297 & 1634.684 & 0.000000 \\
\hline & TDN & -0.492054 & 0.089367 & 30.316 & 0.000000 \\
\hline & Site & --- & --- & 107.336 & 0.000000 \\
\hline \multirow{3}{*}{$\begin{array}{c}\text { Heterotrophic } \\
\text { Archaeal } \\
\text { production }\end{array}$} & Intercept & 1.125856 & 0.021440 & 2757.573 & 0.000000 \\
\hline & TDN & 0.139250 & 0.028357 & 24.115 & 0.000001 \\
\hline & Site & --- & --- & 112.124 & 0.000000 \\
\hline
\end{tabular}


https://doi.org/10.5194/bg-2020-60

Preprint. Discussion started: 3 April 2020

(c) Author(s) 2020. CC BY 4.0 License.

Table 3. Summary of the best-generalized linear model (according to AIC) selected for the virus 730 abundance in the sites: Odiel M, VPalma, CGata, SPola, Hondo, and EbroD (see Figure 1 and Table 1). Columns show the estimates, the standard errors, the Wald statistics, and the p-values for the predictor variables. The complete set of alternative (less explanatory) models with $\delta$ AIC $<2.0$ are shown in Supplementary Table S4.

\begin{tabular}{|c|c|r|r|r|r|}
\hline $\begin{array}{c}\text { Dependent } \\
\text { Variables }\end{array}$ & $\begin{array}{c}\text { Predictor } \\
\text { Variables }\end{array}$ & Estimate & \multicolumn{1}{c|}{$\begin{array}{c}\text { Standard } \\
\text { Error }\end{array}$} & \multicolumn{1}{c|}{$\begin{array}{l}\text { Wald } \\
\text { Stat. }\end{array}$} & p-values \\
\hline Virus abundance & Intercept & 1.316355 & 0.053246 & 611.1956 & 0.000000 \\
\hline & Salinity & 0.204842 & 0.028806 & 50.5662 & 0.000000 \\
\hline & Site & --- & --- & 117.4885 & 0.000000 \\
\hline
\end{tabular}

735 
https://doi.org/10.5194/bg-2020-60

Preprint. Discussion started: 3 April 2020

(c) Author(s) 2020. CC BY 4.0 License.

Table 4. Summary of the best-generalized linear model (GLM) (according to AIC) selected for bacterial production. Columns show the estimates, standard errors, Wald statistics, and p-values for the selected predictor variables. The complete set of models with $\delta \mathrm{AIC}<2.0$ are shown in Table S4.

740

\begin{tabular}{|c|c|c|c|c|c|}
\hline $\begin{array}{c}\text { Dependent } \\
\text { Variables }\end{array}$ & $\begin{array}{c}\text { Predictor } \\
\text { Variables }\end{array}$ & Estimate & $\begin{array}{c}\text { Standard } \\
\text { Error }\end{array}$ & $\begin{array}{c}\text { Wald } \\
\text { Stat. }\end{array}$ & p-values \\
\hline $\begin{array}{c}\text { Bacterial } \\
\text { heterotrophic } \\
\text { production }\end{array}$ & Intercept & 5.249544 & 0.334563 & 246.2003 & 0.000000 \\
\hline & Site & --- & --- & 36.5871 & 0.000001 \\
\hline & Salinity & -0.436568 & 0.120411 & 13.1453 & 0.000288 \\
\hline & VA & -0.187402 & 0.066857 & 7.8570 & 0.005062 \\
\hline
\end{tabular}

